\title{
FGF-2 overexpression opposes the beta amyloid toxic injuries to the vascular endothelium
}

\author{
S Donnini ${ }^{1,2}$, S Cantara ${ }^{1,2}$, L Morbidelli ${ }^{1}$, A Giachetti ${ }^{1}$ and \\ M Ziche*,1 \\ 1 Department of Molecular Biology, University of Siena, Via A. Moro 2, 53100 \\ Siena, Italy \\ 2 These authors equally contributed to the work \\ * Corresponding author: M Zichel, Department of Molecular Biology, University \\ of Siena, Via A. Moro 2, 53100 Siena, Italy. Tel: + 390577 234444; \\ Fax: + 390577 234343; E-mail: ziche@ unisi.it
}

Received 13.7.05; revised 20.9.05; accepted 28.9.05; published online 27.1.06 Edited by P Nicotera

\begin{abstract}
Recent evidences suggest that $A \beta$ peptides modulate endothelial cell $(E C)$ functions. At low concentrations, $A \beta_{1-40}$ enhances the pro-angiogenic activity of FGF-2, whereas deposition of excess $A \beta$ causes $E C$ dysfunction and cerebral amyloid angiopathy (CAA). We investigated whether FGF-2 attenuates $E C$ dysfunction caused by pathological $A \beta$ levels. We studied $A \beta_{1-40}$ on EC survival, as well as on signals responsible of their angiogenic phenotype. At 5-50 $\mu \mathrm{M} \mathrm{A} \beta_{1-40}$ reduced EC population, caused apoptosis, downregulated FGF2 production, inhibited FGF-2 binding to heparin, and FGFR1 phosphorylation. Toxic effects were owing to lack of FGF-2 stimulation, as EC overexpressing FGF-2 displayed extraordinary resistance to $A \beta_{1-40}$ injuries. The FGF-2 mechanism responsible for reversing damages, involves the downstream enhancement of Akt, a pathway independent of eNOS activation. In conclusion, we demonstrate that FGF-2 protects $\mathrm{EC}$ from the effects of excess $A \beta_{1-40}$, suggesting that it may attenuate the consequences of $A \beta$ deposition in pathologies as CAA. Cell Death and Differentiation (2006) 13, 1088-1096. doi:10.1038/sj.cdd.4401803; published online 27 January 2006
\end{abstract}

Keywords: angiogenesis; FGF-2; endothelium; cerebral amyloid angiopathy; Akt

Abbreviations: EC, endothelial cell; FGF-2, fibroblast growth factor-2; $\mathrm{A} \beta$, beta amyloid; CAA, cerebral amyloid angiopaty; BCS, bovine calf serum; FCS, fetal cal serum; VEGF, vascular endothelium growth factor; eNOS, endothelial nitric oxide synthase; AD, Alzheimer's disease

\section{Introduction}

$\beta$ amyloid peptides ( $\mathrm{A} \beta$ peptides), regarded as the main causative factors of cerebral amyloid angiopathy (CAA) and Alzheimer's disease (AD), ${ }^{1-4}$ originate from the amyloid precursor protein (APP) through a proteolytic cascade which generates two peptides of different sequence lengths: $\mathrm{A} \beta_{1-40}$ and $\mathrm{A} \beta_{1-42 .}{ }^{5}$
$\mathrm{A} \beta_{1-40}$, being primarily vasculotropic, is found in the brain vasculature of CAA patients and in experimental models of the disease, whereas $\mathrm{A} \beta_{1-42}$, endowed with distinct trophism for neurons, predominates in the brain parenchyma of $A D$ patients. ${ }^{6-9}$ Brain vascular degeneration, typical of both sporadic and genetic variants of CAA, is characterized by perivascular deposition of $A \beta$ in cortical and leptomeningeal vessels. ${ }^{9}$ The hallmark pathological lesion of these diseases is the pervasive dysfunction of brain capillary endothelium. The dysfunction, clearly related to the toxic effects exerted by $\mathrm{A} \beta_{1-40}$ on endothelial cells (ECs), has been extensively described in cultured cells, ${ }^{10}$ in isolated vessels ${ }^{11}$ as well as in whole animals. ${ }^{12}$ Amyloid peptides induce, at fairly high concentrations, seemingly irreversible changes of morphology and functions of ECs, ${ }^{13,14}$ the latter resulting in reduced survival and suppression of their inherent angiogenic properties.

Besides the overwhelming evidence for a pathological role of $\mathrm{A} \beta$ peptides, recent studies have revealed also their benign side, which has been seen both in neurons ${ }^{15}$ and in the endothelium. ${ }^{16}$ Recently, we reported a marked activation of EC basic functions (proliferation, migration) by physiological concentrations (nanomolar) of $A \beta$ peptides. ${ }^{16}$ Surprisingly, we also uncovered a specific interaction, and indeed a striking synergism, between $\mathrm{A} \beta$ peptides and fibroblast growth factor2 (FGF-2). This interaction promotes the intracellular synthesis of FGF-2, yielding an enhanced viability of microvascular endothelium, as well as the expression of robust angiogenic responses. ${ }^{16}$ These findings raise the question whether the endothelial toxic injuries exhibited by pathological concentrations of $A \beta_{1-40}$ might be linked to an impairment of the production of FGF-2, a growth factor crucially implicated in the survival/repair mechanisms of the endothelium. ${ }^{17} \mathrm{~A}$ related question is whether FGF-2 overexpression could prevent the endothelial dysfunction invariably associated with the progression of CAA. To answer these questions, we selected a moderately high concentration of $\mathrm{A} \beta_{1-40}$, producing borderline toxic effects on cells, examining its influence on cell viability, endogenous FGF-2 production, and EC responsiveness to other angiogenic factor such as VEGF. We, also, examined how ECs, specifically engineered to overexpress FGF-2, would counteract the $A \beta$ peptides toxic lesions and the mechanisms implicated in FGF-2-induced protection, analysing ERK1/2 and Akt phosphorylation, as well as eNOS activity. The evidence gathered in this study clearly indicates that FGF-2 reverts endothelial dysfunction, suggesting that its delivery to injured cells might be a useful therapeutic intervention to attenuate the progression of CAA.

\section{Results}

\section{$A \beta_{1-40}$ affects endothelial cell survival and activates caspase- 3 activity}

First, we investigated the toxic injuries exerted by $\mathrm{A} \beta_{1-40}$ on the survival capacity of quiescent ECs of different lineage and 
characteristics. We selected three cell lines: CVEC, microvascular ECs isolated from bovine postcapillary venular vessels, MAE, macrovascular ECs, from mouse aorta, and pZIPbFGF, a cell line derived from MAE, which express high levels of $M_{\mathrm{r}} 18,22$ and $24 \mathrm{kDa} F \mathrm{FF}-2$ isoforms under the control of the Mo-MuLV LTR elements of the pZIPNeoSV $(X)$ vector, ${ }^{17}$ and release approximately $100 \mathrm{pg} / 96 \mathrm{~h} / 10^{6}$ cells, as evaluated by immunoassay. ${ }^{18}$

In the survival experiments, the initial conditions (confluence, quiescence) were comparable for all lines examined.

The pattern of cell survival differed greatly among cell types, particularly at low micromolar concentrations of $\mathrm{A} \beta_{1-40}$. At $0.5 \mu \mathrm{M}, \mathrm{A} \beta_{1-40}$ did not affect the survival of either pZIPbFGF or CVEC (Figure 1a). Indeed, in the latter cell line we observed a significant $(P<0.01)$ stimulatory effect, undoubtedly the tailend of pro-proliferative activity recently observed at peptide nanomolar concentrations. ${ }^{16}$ In contrast, the cell loss was severe in MAE $(60 \%$ at $5 \mu \mathrm{M})$, and worsened up to 75 and $97 \%$ with the rise of peptide concentrations (50 and $100 \mu \mathrm{M}$, respectively) (Figure 1a). In CVEC, the ability to survive was reduced starting from $5 \mu \mathrm{M}$ of $\mathrm{A} \beta_{1-40}$ (40\% loss), declining gradually thereafter (60 and $90 \%$ loss at 50 and $100 \mu \mathrm{M}$, respectively) (Figure 1a). The decline of survival capacity was significantly lower in pZIPbFGF relative to the other cell lines, being nil at $5,35 \%$ at $50(P<0.001)$, and $50 \%$ at $100 \mu \mathrm{M}$ $(P<0.001)$ (Figure 1a). The reverse-sequence $\mathrm{A} \beta_{40-1}(50 \mu \mathrm{M}$, not shown) did not affect survival in any cell lines, indicating $\mathrm{A} \beta_{1-40}$ specificity. As we were interested in relating our investigation to the initial, possibly reversible, events of the microvascular pathology, we performed most studies at $5 \mu \mathrm{M}$ peptide, which produced borderline endothelial cell injury.

In light of the observed cell loss, we investigated whether $\mathrm{A} \beta_{1-40}$ might induce cell death through caspase cascade.
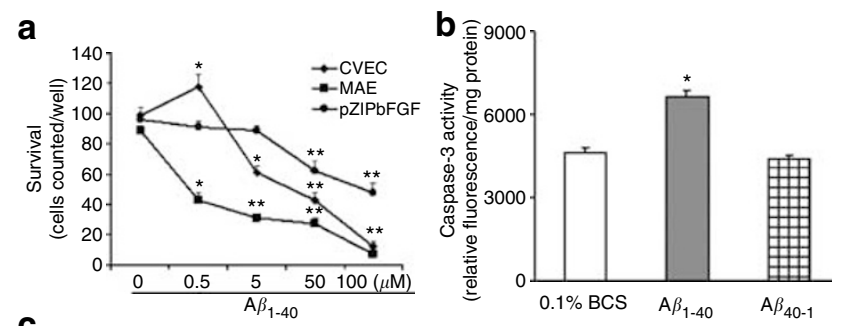

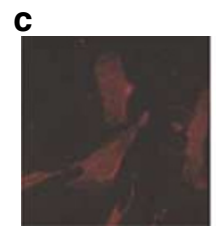

$0.1 \% \mathrm{BCS}$

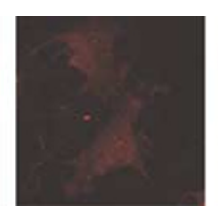

$0.5 \mu \mathrm{M}$

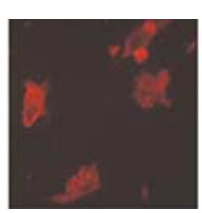

$5 \mu \mathrm{M}$

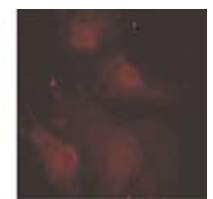

$\mathrm{A} \beta_{40-1} 5 \mu \mathrm{M}$

Figure $1 \mathrm{~A} \beta_{1-40}$ affects endothelial cell survival and activates apoptosis. (a) Sparse, synchronized endothelial cells (CVEC, MAE and pZIPbFGF) were exposed to $\mathrm{A} \beta_{1-40}(0.5-100 \mu \mathrm{M})$. Data are reported as cell number counted/well. $(n=4){ }^{*} P<0.01$ and ${ }^{* *} P<0.001$ versus $0.1 \%$ serum by Student's $t$-test. (b) CVEC were exposed to $\mathrm{A} \beta_{1-40}$, or to reverse peptide (both at $5 \mu \mathrm{M}$ ) for $18 \mathrm{~h}$, and caspase- 3 was measured by rhodamine-based fluorimetric assay as outlined in methods $(n=4){ }^{*} P<0.01$ versus $0.1 \%$ serum alone. (c) Occurrence of apoptosis was morphologically monitored by immunofluorescence assay. Representative pictures of control condition, $\mathrm{A} \beta_{1-40}(0.5$ and $5 \mu \mathrm{M})$, or $\mathrm{A} \beta_{40-1}$ $(5 \mu \mathrm{M})$, respectively, from left to right. Original magnification at $\times 400$

$\mathrm{A} \beta_{1-40}(5 \mu \mathrm{M}$ for $16 \mathrm{~h})$ induced in CVEC caspase-3 activation (36\%, $P<0.01$ ) (Figure 1b). Caspase-3 activation was revealed also by immunohistochemistry staining which evidenced an increased fluorescence in cell population treated with $\mathrm{A} \beta_{1-40}(5 \mu \mathrm{M})$, whereas, the lower concentration $(0.5 \mu \mathrm{M})$, and its reverse peptide showed the same fluorescence pattern as cells cultured in $0.1 \%$ BCS (Figure 1c).

\section{$A \beta_{1-40}$ impairs FGF-2 production and endothelial cell survival: reversal by engineered overexpression of FGF-2}

Because the above experiments hinted to the dependence of cell survival from FGF-2, we examined its endogenous production in all cell lines, following their exposure to $\mathrm{A} \beta_{1-40}$ in the $0.5-50 \mu \mathrm{M}$ range. In CVEC, a detectable decline of FGF-2 production occurred at $5 \mu \mathrm{M}$ (47\% versus control), whereas in MAE the expression was abolished at this concentration (96\% versus control), the decrease being noticeable even at $0.5 \mu \mathrm{M}$ (Figure $2 \mathrm{a}$ and $\mathrm{b}$ ). In contrast, $\mathrm{A} \beta_{1-40}$ marginally affected the FGF-2 expression in pZIPbFGF, as significant decline was observed only at $50 \mu \mathrm{M}$ (Figure 2c).

Based on this evidence, showing the importance of FGF-2 in preserving endothelial integrity, we hypothesized that overexpression of endogenous FGF-2 production would overcome the $\mathrm{A} \beta_{1-40}$-induced decline of angiogenic drive. To test this hypothesis, we compared MAE and pZIPbFGF, seeded on fibrin-embedded microcarriers, for their ability to generate pseudocapillaries in the presence/absence of $\mathrm{A} \beta_{1-40}(5 \mu \mathrm{M})$ (Figure $2 \mathrm{~d}$ ). Pseudocapillaries were strikingly more abundant in pZIPbFGF than in MAE $(141 \pm 12$ versus $36 \pm 5, P<0.001)$. Exposure to $\mathrm{A} \beta_{1-40}$ reduced pseudocapillaries formation in MAE $(76 \%$ inhibition, $P<0.01)$, whereas in pZIPbFGF a slight sprouting increase was noted $(+40 \%$, $P<0.01$ ) (Figure $2 d$ ). Pictures of endothelial sprouts emanating radially from $\mathrm{A} \beta_{1-40}$-treated microcarriers, show a faint pseudocapillary network in MAE, contrasting with the rich sprouting obtained in FGF-2 transfectants (Figure 2e). Collectively, these data provide evidence for a FGF-2 role in promoting endothelial sprouting and in preserving the angiogenic phenotype in face of $A \beta$-induced injuries.

As $\mathrm{A} \beta_{1-40}$ appears to target the FGF-2 pathway to induce endothelial toxicity, we examined whether the peptide would interfere with its membrane binding sites. First, we measured the $\mathrm{A} \beta_{1-40}$ ability to influence FGF-2 binding in vitro to heparin, a membrane molecule which functions as an intermediate site for the factor. ${ }^{19}$ Pre-incubation with $\mathrm{A} \beta_{1-40}(0.05-50 \mu \mathrm{M})$ inhibited FGF-2 ( $25 \mathrm{ng}$ ) binding to heparin-coated beads in a concentration-dependent manner (Figure 2f). This indicates that the FGF-2 binding to its intermediate storage sites is severely affected by $\mathrm{A} \beta_{1-40}$ concentrations higher than $5 \mu \mathrm{M}$. Next, we examined whether $\mathrm{A} \beta_{1-40}$ would affect the activation of the FGF-2 receptor subtype 1. In $\mathrm{CHO}$ cells transfected with mouse FGFR1, exposure to the peptide halved the phosphorylation of the receptor at $0.5 \mu \mathrm{M}$ and reduced it approximately tenfold at $5 \mu \mathrm{M}$ (OD: $0.86,0.43,0.12$ for $0.05,0.5$ and $5 \mu \mathrm{M}$, respectively, versus 1.07 for FGF-2) (Figure $2 \mathrm{~g}$ ). 
a
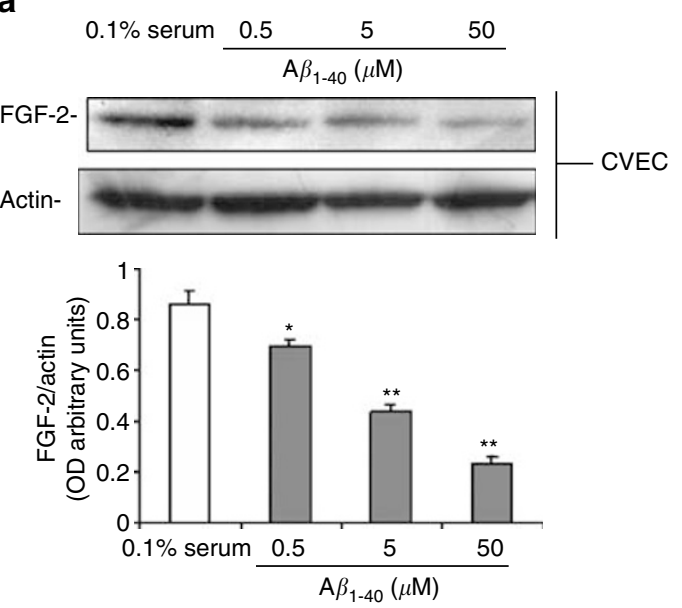

C
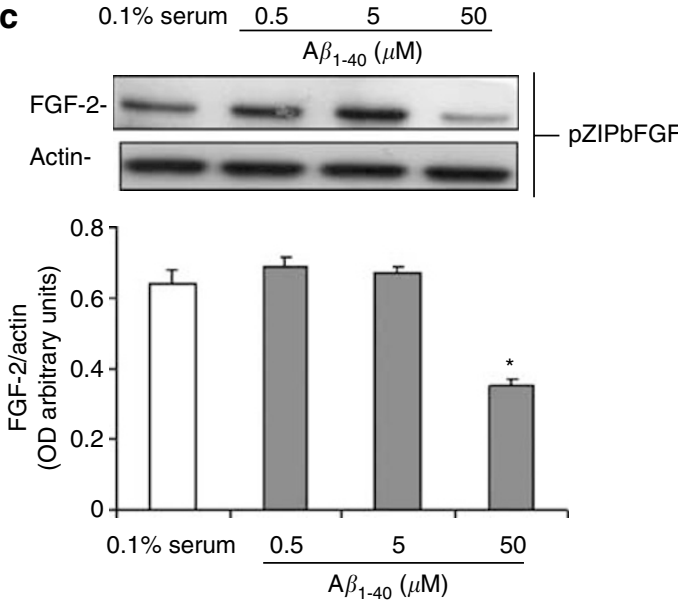

f
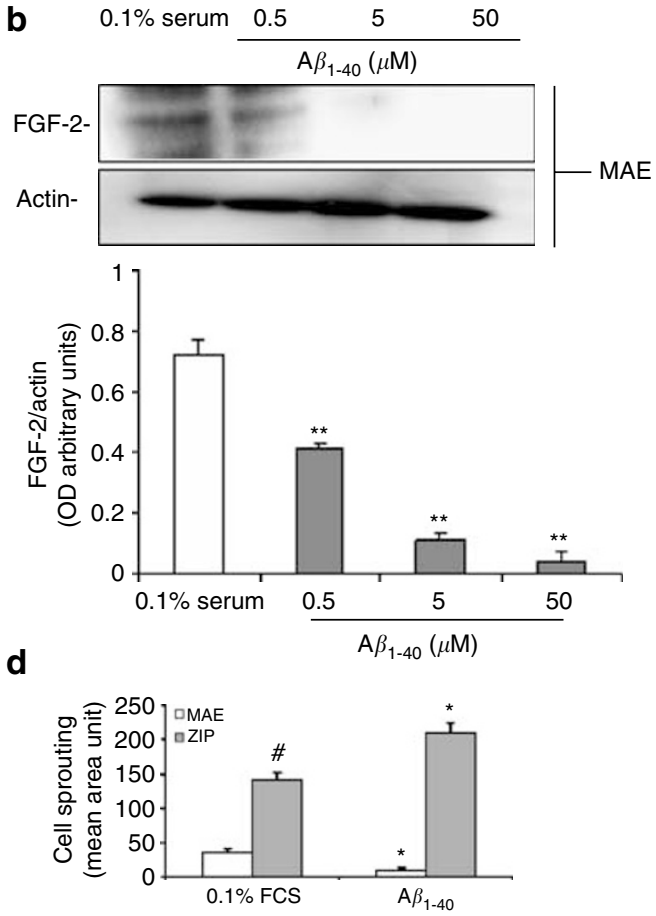

e

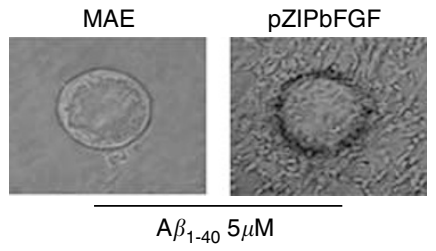

g

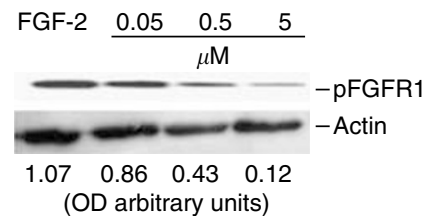

Figure 2 FGF-2 overexpression counteracts $A \beta$-induced toxic effect. The effect of $\mathrm{A} \beta_{1-40}(0.5-50 \mu \mathrm{M}$ for $16 \mathrm{~h})$ on FGF-2 production in CVEC (a), MAE (b) and pZIPbFGF (c), was assessed by Western blotting. A representative gel out of three with similar results is shown. Bar graph represents FGF-2 optical density (mean of three experiments \pm s.e.m.). ${ }^{\star} P<0.001$ versus $0.1 \%$ serum by Student's $t$-test. (d) MAE or pZIPbFGF were grown on microcarries, then embedded in fibrin gel. Incubation carried out for 7 days. Vessel sprouting is monitored by an inverted microscope at $\times 20$ magnification, using an ocular grid. Area covered by capillaries in MAE or pZIPbFGF in control condition $\left(0.1 \%\right.$ serum), or following $A \beta_{1-40}(5 \mu \mathrm{M})$, is shown. ${ }^{*} P<0.01$ versus basal response and ${ }^{\#} P<0.001 \mathrm{pZIPbFGF}$ versus MAE in control conditions by Student's $t$-test. (e) Representative pictures of $A \beta_{1-40}(5 \mu \mathrm{M})$-induced cell sprouting, are reported for MAE and pZIPbFGF. (f) FGF-2 heparin binding inhibited by $A \beta_{1-40}$. Acrylic heparin beads were treated with $\mathrm{A} \beta_{1-40}$ from 0.05 to $50 \mu \mathrm{M}$ for $1 \mathrm{~h}$ at $37^{\circ} \mathrm{C}$, then incubated with FGF-2 (25 ng). Bound FGF-2 was recovered and revealed by Western blot. $(n=3)$. (g) FGFR1 phosphorylation measured in $\mathrm{CHO}$ cells. Cells were incubated with $\mathrm{A} \beta_{1-40}$ from 0.05 to $5 \mu \mathrm{M}$ for 5 min; receptor activation was evaluated with anti-phospho-tyrosine antibody. Results were normalized with actin $(n=3)$

\section{$A \beta_{1-40}$ reduces endothelial responses to VEGF}

Because the maintenance of a viable endothelium depends also on the presence of exogenous growth factors, mainly vascular endothelial growth factor (VEGF), we examined whether exposure to $\mathrm{A} \beta_{1-40}$ would modify the responsiveness of CVEC to VEGF.

VEGF, as expected, produced stimulation of CVEC growth and migration. Application of $\mathrm{A} \beta_{1-40}(5 \mu \mathrm{M})$ abolished the proliferative response to VEGF $(P<0.01$ versus $0.1 \%$ BCS; $P<0.001$ versus VEGF-induced cell growth) (Table 1 ). Similarly, the amyloid peptide exerted a profound inhibitory effect on the VEGF-enhanced cell migration $(P<0.001)$ (Table 1), and on the release of MMPs (data not shown).

VEGF is known to stimulate the angiogenic phenotype in CVEC through the enhanced expression of FGF-2 and eNOS activation. ${ }^{20}$ VEGF-induced expression of both these signals was found to be severely abated by $\mathrm{A} \beta_{1-40}(5 \mu \mathrm{M})$, which reduced their expression to levels below control (eNOS: 3000 versus $7000 \mathrm{DPM} / \mathrm{mg}$; FGF-2 expression OD: 0.28 versus 0.9 ) (Figure $3 a$ and $b$, respectively). Similarly, $A \beta_{1-40}$, which had no effect on ERK1/2 phosphorylation in quiescent cells, markedly attenuated that stimulated by VEGF, reproducing in biochemical terms the effects noted on cell growth (Figure $3 c$ ). 
A $\beta_{1-40}$-induced impairment of functions was also reflected on in vivo angiogenesis. To mimic amyloid pathological deposition, we enriched the corneal stroma of rabbits by delivering $\mathrm{A} \beta_{1-40}$ through implanted micropellets, prior the VEGF challenge. $\mathrm{A} \beta_{1-40}$ dose-dependently (50-500 ng/pellet) reduced the VEGF-promoted angiogenesis, resulting in significantly lower angiogenic scores (Figure 3d). A $\beta_{1-40}$ peptide, when tested alone, did not produce any inflammatory or angiogenic response.

\section{FGF-2 protects from $A \beta_{1-40}$ toxicity by enhancing Akt phosphorylation}

Because the above experiments clearly illustrated the protection of FGF-2 toward $\mathrm{A} \beta_{1-40}$ toxicity, we further

Table $1 \mathrm{~A} \beta_{1-40}$ effect on endothelial cell growth and migration induced by VEGF

\begin{tabular}{lcc}
\hline & $\begin{array}{c}\text { Cell growth } \\
\text { (cells counted/well) }\end{array}$ & $\begin{array}{c}\text { Migration } \\
\text { (cells counted/well) }\end{array}$ \\
\hline $0.1 \%$ BCS & $103 \pm 9$ & $27 \pm 4$ \\
VEGF & $153 \pm 12^{*}$ & $69 \pm 6^{*}$ \\
$\mathrm{~A} \beta_{1-40}$ & $59 \pm 8^{*}$ & $26 \pm 2$ \\
$\mathrm{~A} \beta_{1-40}+$ VEGF & $65 \pm 9^{\#}$ & $22 \pm 7^{\#}$ \\
\hline
\end{tabular}

CVEC were treated with $A \beta_{1-40}(5 \mu \mathrm{M})$ in the presence/absence of VEGF (20 ng $\mathrm{ml})$. Cell growth was measured after $48 \mathrm{~h}$, whereas cell migration was conducted for $4 \mathrm{~h}$. Results are reported as cells counted/well \pm s.e.m. $(n=3)$ ${ }^{*} P<0.01$ versus $0.1 \%$ BCS, ${ }^{\#} P<0.001$ versus VEGF-induced responses analyzed its mechanism, by monitoring Akt, a signal implicated in endothelial survival. ${ }^{21} \mathrm{FGF}-2(20 \mathrm{ng} / \mathrm{ml})$ promoted Akt phosphorylation with maximal activity at $15 \mathrm{~min}$ (Figure $4 \mathrm{a}) . \mathrm{A} \beta_{1-40}(5 \mu \mathrm{M})$, at this time point, sharply reduced (72\%, $P<0.01$ ) Akt phosphorylation in CVEC (Figure 4a). FGF-2 application prevented the effect of $\beta$ amyloid on Akt activity $(P<0.01)$ and, on the contrary, promoted Akt phosphorylation by $52 \%$ compared to the basal condition (0.1\% serum) (Figure $4 a)$.

The consequences of interfering with the survival signal changes were revealed by Tunel assay in CVEC exposed to $\mathrm{A} \beta_{1-40} \quad(5 \mu \mathrm{M}$ for $16 \mathrm{~h}) . \quad \mathrm{A} \beta_{1-40}$ application decreased cell number and increased caspase-3-related fluorescence (Figure $4 \mathrm{~b}$ second panel) compared to control (Figure $4 \mathrm{~b}$ first panel) and FGF-2 treated cells (Figure 4b third panel). FGF-2 reverted both cell density and fluorescence to control levels, thus rescuing cells from apoptosis induced by $\mathrm{A} \beta_{1-40}$ (Figure $4 \mathrm{~b}$ fourth panel). The reverse $\mathrm{A} \beta_{40-1}$ sequence showed no effects (Figure $4 \mathrm{~b}$ fifth panel). As Akt phosphorylation promotes survival through eNOS activation in cultured $E C s,{ }^{21}$ we investigated the effects of either $\mathrm{A} \beta_{1-40}(5 \mu \mathrm{M})$ or FGF-2 $(20 \mathrm{ng} / \mathrm{ml})$ alone or combined, on eNOS activity in CVEC. Consistently with literature data, ${ }^{10,13,16}$ eNOS activity in cell treated with $\mathrm{A} \beta_{1-40}$ was sharply reduced (Figure $4 \mathrm{c}$ ). The suppression of eNOS constitutive activity exerted by $\mathrm{A} \beta_{1-40}$ was insensitive to FGF-2 addition (Figure $4 \mathrm{c}$ ), suggesting that survival

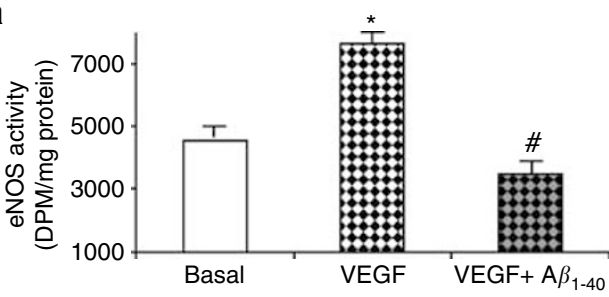

C
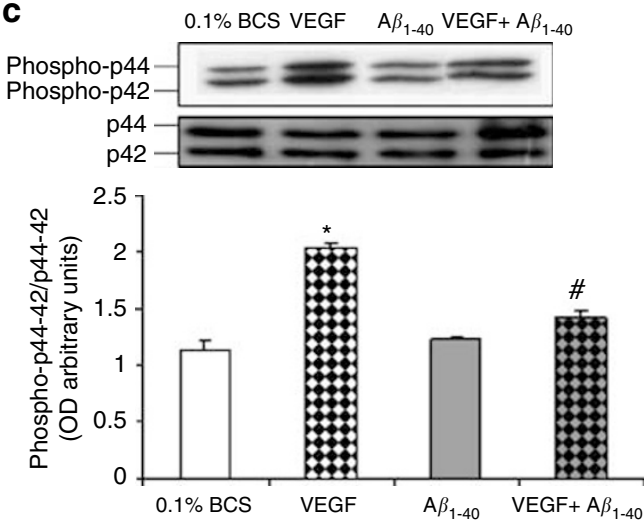

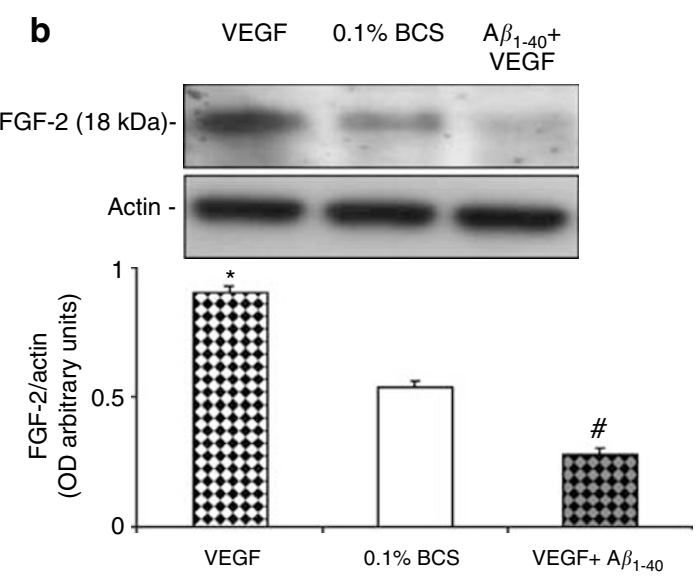

d

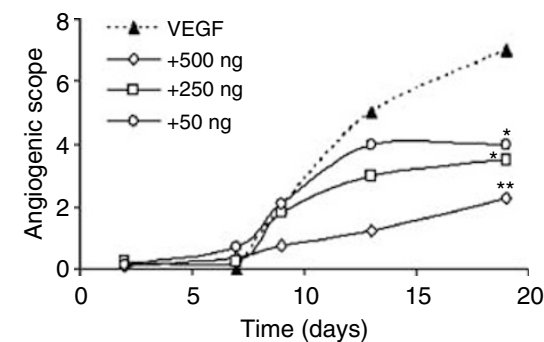

Figure $3 \quad \mathrm{~A} \beta_{1-40}$ impairs the pro-angiogenic effect of VEGF in CVEC. (a) CVEC were treated with $\mathrm{A} \beta_{1-40}(5 \mu \mathrm{M})$, then stimulated with VEGF $(20 \mathrm{ng} / \mathrm{ml})$ for $1 \mathrm{~h}$. eNOS activity was measured as conversion of [3H]-L-arginine in [3H]-L-citrulline. Data are reported as DPM/mg protein. ${ }^{*} P<0.05$ versus control and ${ }^{\#} P<0.05$ versus VEGF alone by ANOVA. The enzyme specificity was assessed by using L-NMMA ( $2 \mathrm{mM}$, values subtracted) $(n=3)$. (b) A $\beta$ inhibits VEGF-induced FGF-2 protein expression in CVEC. Normalization performed with actin. Numbers are the ratio FGF-2/actin OD relative units \pm s.e.m. (c) A $\beta_{1-40}$ impairs VEGF-induced ERK1/2 phosphorylation. Results were normalized with total ERK1/2. The gels shown are representative of three obtained with similar results. ${ }^{*} P<0.01$ versus control and ${ }^{\#} P<0.01$ versus VEGF-induced phosphorylation by ANOVA. (d) A $\beta$ dose dependently inhibited VEGF-induced in vivo angiogenesis. Corneas were enriched for 7 days by implanting pellets with $A \beta_{1-40}(50-500 \mathrm{ng} /$ pellet). Pellets were substituted at day 7 with pellets bearing VEGF $(200 \mathrm{ng})$. Angiogenesis was monitored and quantified as angiogenic score at times indicated. Each score is the mean of at least three implants. ${ }^{*} P<0.01$ and ${ }^{* \star} P<0.001$ at day 20 versus VEGF-induced response by Student's $t$-test 
a
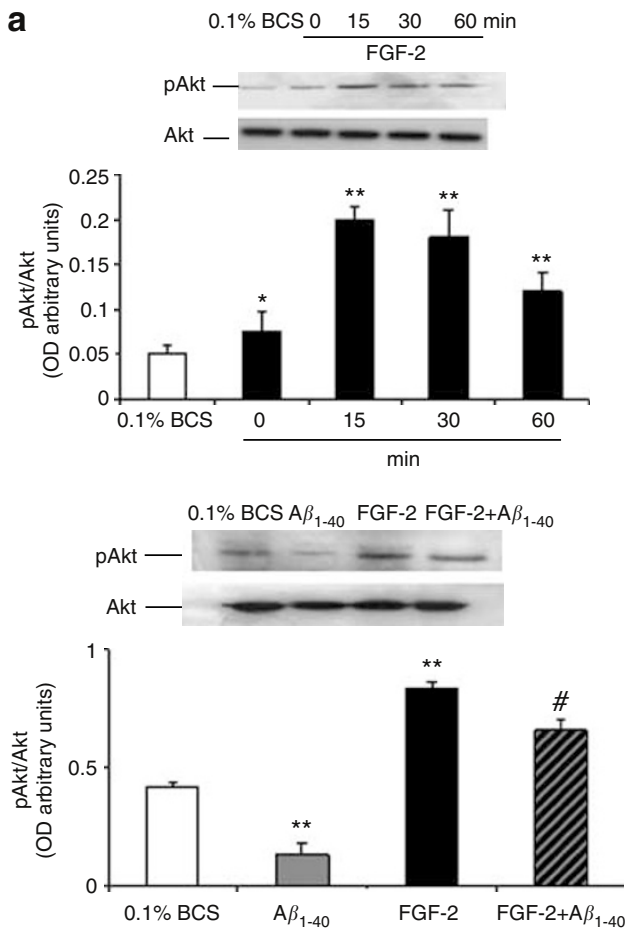

b

$0.1 \% \mathrm{BCS}$
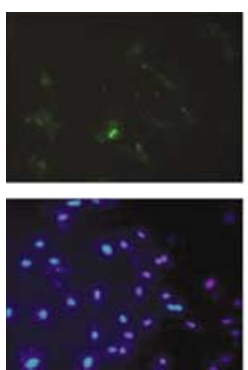

$\mathrm{A} \beta \beta_{1-40}$
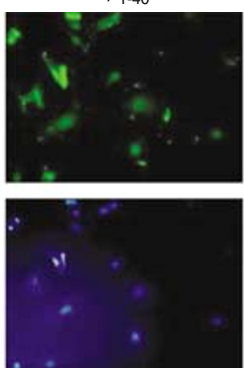

C

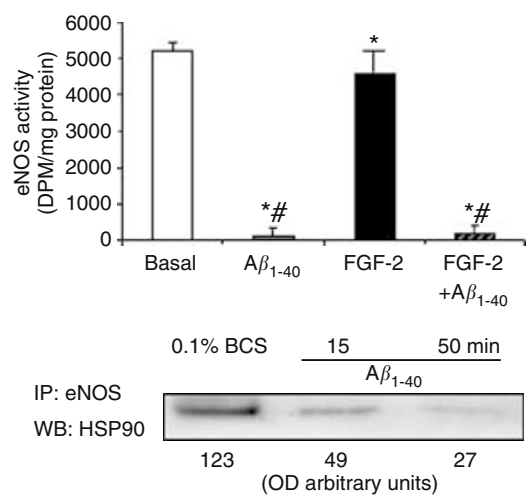

e

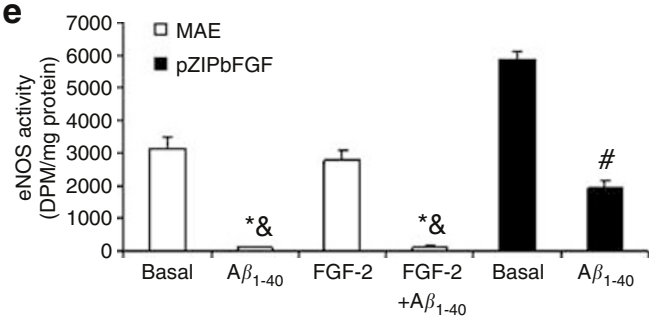

FGF-2
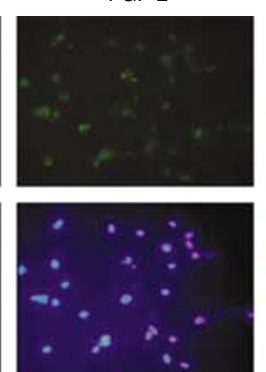

$\mathrm{A} \beta_{1-40}+\mathrm{FGF}-2$
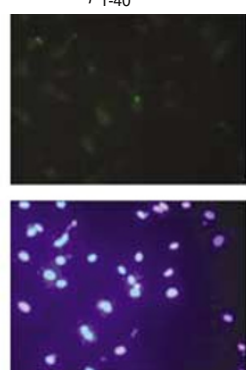
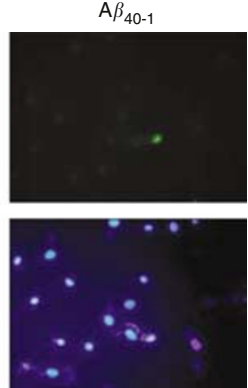

Figure 4 FGF-2 protection is mediated by Akt phosphorylation but not eNOS activation. (a) Activation of Akt following FGF-2 (20 ng/ml) treatment for $0,15,30$ and $60 \mathrm{~min}$ (upper panel). Effect of $\mathrm{A} \beta_{1-40}(5 \mu \mathrm{M})$ on Akt phosphorylation induced by FGF-2 (20 ng/ml, $15 \mathrm{~min}$ ) (lower panel). Akt phosphorylation was evaluated by Western blot. Results were normalized with total Akt. Bar graph represents the mean of three experiments expressed as pAkt/Akt \pm s.e.m. ${ }^{\star \star} P<0.01$ versus control, ${ }^{\#} P<0.01$ versus $\mathrm{A} \beta_{1-40}$-induced inhibition by ANOVA. (b) A $\beta_{1-40}$ induced apoptotic cell death (green fluorescence) restored by FGF-2 (20 ng/ml) administration. Representative pictures of controls, $A \beta_{1-40}$, FGF-2, $\mathrm{A} \beta_{1-40}+\mathrm{FGF}-2$ or $\mathrm{A} \beta_{40-1}(5 \mu \mathrm{M})$, respectively from left to right. Apoptosis was monitored by Tunel assay. Total cells were counterstained with DAPI which stained cell nuclei in blue (lower pictures). Original magnification at $\times 40$. (c) CVEC were exposed for $1 \mathrm{~h}$ to $\mathrm{A} \beta_{1-40}(5 \mu \mathrm{M})$ in presence/ absence of FGF-2, and then eNOS activity was measured. Results are expressed as DPM/mg protein, LNMMA ( $2 \mathrm{mM}$ ) value subtracted. ${ }^{*} P<0.001$ versus control, ${ }^{\#} P<0.001$ versus FGF-2 by ANOVA $(n=3)$. (d) CVEC were treated as above, then cell lysates were immunoprecipitated for eNOS and immunoblotted for HSP90. The gel shown in figure is representative of three obtained with similar results. (e) eNOS activity measured in MAE and pZIPbFGF either after exposure to $\mathrm{A} \beta_{1-40}(5 \mu \mathrm{M}$, $50 \mathrm{~min})$ or FGF-2 $(20 \mathrm{ng} / \mathrm{ml}, 15 \mathrm{~min})$ alone or combined. L-NMMA $(2 \mathrm{mM})$ value subtracted. Results are reported as DPM/mg protein. ${ }^{\star} P<0.001$ versus control; ${ }^{\&} P<0.001$ versus FGF-2 for MAE and ${ }^{\#} P<0.0001$ versus control for $\mathrm{pZIPbFGF}$ by ANOVA $(n=3)$

properties exerted by FGF-2 in CVEC may not be associated with eNOS activation.

Further, we measured HSP90 recruitment, a chaperon protein closely linked to eNOS activation, following immunoprecipitation of its complex with eNOS. $\mathrm{A} \beta_{1-40}$ markedly diminished HSP90 recruitment in CVEC both at 15 or $50 \mathrm{~min}$, as evidenced by immunoblotting (Figure 4d). Consistent with the above results, the constitutive eNOS activity was severely inhibited by $\mathrm{A} \beta(5 \mu \mathrm{M})$ in MAE and pZIPbFGF clones and remained insensitive to simultaneous FGF-2 application (Figure $4 \mathrm{e}$ ), indicating that in the presence of $\mathrm{A} \beta_{1-40}$, neither external nor endogenous FGF-2 engages eNOS for their survival.
These results demonstrate that FGF-2 promotes endothelial survival through activation of Akt with a mechanism independent from eNOS activation.

\section{Discussion}

Disruption of angiogenesis is regarded as one of the mechanisms contributing to the development of CAA. ${ }^{22}$ Because of their involvement in the pathogenesis of this degenerating disease, $\mathrm{A} \beta$ peptides are viewed as sinister molecules causing irreparable damages to ECs. However, this view might be tempered by the findings, here reported, showing that endothelial injuries inflicted by $\mathrm{A} \beta$ peptides may 
be prevented/repaired by conditions that favour the overexpression of FGF-2.

Vascular ECs, although susceptible to toxic injuries caused by $A \beta$ peptides, appear to possess an extraordinary resilience to external insults. This feature, not reported before, is attributed to a survival programme driven by the endogenous synthesis of FGF-2, which acts in autocrine-paracrine mode to maintain cell viability.

$\mathrm{A} \beta_{1-40}$ did exert toxic effects on ECs as indicated by the decline of cell population and by the reduced viability. Cell loss caused by $\mathrm{A} \beta_{1-40}$ occurred in a concentration-related fashion in the micromolar range. Interestingly, sub-micromolar concentrations $(0.5 \mu \mathrm{M})$ evoked growth rather than loss in CVEC, an effect related to a specific interaction of $A \beta$ peptides with FGF-2, previously reported from this laboratory. ${ }^{16} \mathrm{~A}$ number of studies have previously described the $A \beta$ peptide toxicity on the endothelium with similar results. ${ }^{11,23}$ Emerging from this study is the different sensitivity to $A \beta_{1-40}$ between cells originating from large vessels exemplified by MAE, and ECs derived from microvessels such as CVEC. An even greater resistance to $A \beta$ was observed in the FGF-2 transfectant cell line, that is, pZIPbFGF, a finding that offered the first clue for the importance of FGF-2 in fostering cell survival (see below). EC loss induced by $A \beta_{1-40}$ was certainly owing to the documented activation of the pro-apoptotic caspase-3 activity, a finding also described in previous studies. ${ }^{24-25}$

The precipitating event leading to $\mathrm{A} \beta_{1-40}$-induced endothelial dysfunction, is the reduced production of FGF-2 noted at varying degrees in all $E C$ lines exposed to the peptide. The FGF-2 decline, greater in MAE and CVEC (in this order) than in $\mathrm{PZIPbFGF}$ cells, remarkably coincides with their respective survival capacity when exposed to $A \beta_{1-40}$. The relationship between FGF-2 expression and the ability of the endothelium to withstand $A \beta_{1-40}$ injuries is strengthened by the sharp differences in pseudocapillary sprouting noted between MAE and $\mathrm{pZIPbFGF.} \mathrm{A} \beta_{1-40}$ abolished pseudo-capillaries sprouting in MAE, whereas in pZIPbFGF sprouting remained as florid as in controls. Consistently, FGF-2 has been found to afford protection toward the endothelial damage produced by gp120, an HIV-derived cytoxic protein, ${ }^{26}$ as well as to shield neuronal cells from the excitotoxicity induced by $A \beta$ peptides. ${ }^{27}$ Conceivably, a mechanism that explains the $A \beta_{1-40}$ toxicity, is the observed disruption of the FGF-2 binding to heparin, a membrane molecule that regulates its subsequent binding to the high-affinity receptor. ${ }^{19}$ The marked reduction of FGFR1 phosphorylation following exposure to $A \beta_{1-40}$, constitutes prima facie evidence that the above mechanism may be operant and may trigger the toxic injuries, as it deprives the endothelium of the tonic FGF-2 input necessary for its survival.

Rescuing endothelial dysfunction, at least that caused by pathological $\mathrm{A} \beta$, appears to be a specific property of FGF-2, VEGF, a growth factor that potently activates $\mathrm{ECs}^{28,29}$ failed to restore signals such as eNOS activity, ERK $1 / 2$ phosphorylation and FGF-2 production, severely muted by $\mathrm{A} \beta_{1-40}$ application. Indeed, the peptide inhibited in a dose-related fashion the in vivo angiogenic response to VEGF in rabbits. Thus, FGF-2, acting in autocrine-paracrine manner, emerges as a molecule endowed with the role of maintaining cell viability and preventing/repairing lesions caused by noxious agents.
Analysis of signals such as Akt, known to be part of the FGF-2 signaling cascade, and eNOS provided evidence for their relative importance in fostering endothelial survival. Akt, a kinase that acts as a brake to apoptotic proteins, was found to be inherently activated in CVEC, possibly through the tonic input of endogenous FGF-2, and further stimulated by exogenous supply of the growth factor. Interference of $\mathrm{A} \beta_{1-40}$ with FGF-2 binding to heparin and/or FGFR, explains the suppression of Akt phosphorylation, because it prevents message transmittal. Notable, however, was the ability of excess exogenous FGF-2 to completely recover Akt activity. Others have reported a partial reversal of intracellularly generated $A \beta_{1-42}$ injuries by Akt in HUVEC, ${ }^{30}$ although the significance of endogenously generated $A \beta_{1-42}$ is questionable in endothelium.

Thus, the activation of Akt signals the survival program operated by FGF-2 to revert apoptosis induced by $\mathrm{A} \beta_{1-40}$.

eNOS, a well-recognized promoter of endothelial integrity and survival, ${ }^{20,31}$ was inhibited by $\mathrm{A} \beta_{1-40}$ in its ability to produce NO through enzymatic activity. However, at variance with Akt, this signal was not restored by exogenous FGF-2. Tentatively, the inhibition of eNOS may be linked to the suppression of HSP90/eNOS complex found in cells treated with $\mathrm{A} \beta_{1-40}$, as this chaperon protein is essential for eNOS activation. ${ }^{32}$ How the amyloid might influence HSP90/eNOS complex is a matter of further investigation. Collectively, the studies on signals helped in delineating the FGF-2 pathway as an autocrine mechanism capable to rescue ECs from damages caused by $\mathrm{A} \beta_{1-40}$ independently from the eNOS pathway.

The evidence here reported, showing the crucial role of FGF-2 expression in reverting $A \beta$-induced lesions, has implications for strategies that aim at reducing the burden of CAA evolution. Recently, de la Torre in the context of the vascular dysfunction, frequently associated with Alzheimer's disease, has hypothesized the use of growth factors, specifically FGF-2 and VEGF, to promote neo-angiogenesis as a mean to alleviate the pervasive cerebral endothelial dysfunction. ${ }^{33}$ This is in analogy with the application of FGF-2 in human trials for intermittent claudication, a disease that recognizes peripheral vasculopathy as the main causative factor. ${ }^{34}$ The findings of this study provide the experimental framework for a similar approach for CAA. In addition, FGF-2, which has been shown to have very promising neuroprotective effects in a number of experimental conditions involving neuronal damage,${ }^{35}$ might exert beneficial effects on neuronal deficits present in advanced $C A A$ as well as in $A D$.

In summary, these results that indicate a novel role of endogenous FGF-2 in preserving endothelium from $A \beta$ induced damages, also imply that its pro-angiogenic activity may be exploited to activate brain neo-angiogenesis in an attempt to reduce the burden of CAA.

\section{Materials and Methods}

\section{Cell culture}

Post-capillary venular endothelial cells (CVEC) were obtained and cultured as previously described. ${ }^{20,31}$ Mouse aortic endothelial cells (MAE) and MAE transfected with human FGF-2 cDNA (pZIPbFGF) were provided by $M$ Presta (Brescia University, Italy), and cultured as 
reported. ${ }^{17}$ pZIPbFGF cells were obtained by transfection of MAE cells with the retroviral expression vector $\operatorname{pZIPNeoSV}(X)$ containing a $1.1 \mathrm{~kb}$ insert of the human FGF2 cDNA. ${ }^{36}$

Chinese hamster ovary (CHO) cells transfected for FGF-R1 were provided by M Presta (University of Brescia, Italy) and cultured as reported. ${ }^{37}$

\section{Cell survival}

A total of $1.5 \times 10^{3}$ cells resuspended in $10 \%$ serum were seeded in each well of 96 multiplate. After adherence $(5-6 h)$, the supernatant was replaced with a medium containing $0.1 \%$ serum (BCS for CVEC and FCS for MAE and pZIPbFGF $)^{38}$ and after $24 \mathrm{~h}$ cells were incubated with $\mathrm{A} \beta_{1-40}$ or reverse sequence peptide $A \beta_{40-1}(0.5-100 \mu \mathrm{M})$. After $48 \mathrm{~h}$, cells were fixed in $100 \%$ methanol and stained with Diff-Quik (Mertz-Dade). Total cell number/well was counted at $100 \times$ magnification. Data are expressed as percentage of cells over basal control or number of cells counted/well.

\section{Cell migration}

Chemotaxis experiments were performed with the Boyden chamber technique (48-well microchemotaxis chamber) as previously described. ${ }^{38}$ To assess whether $A \beta$ was able to influence VEGF-induced migration, cells were pre-incubated with $5 \mu \mathrm{M} \mathrm{A} \beta_{1-40}$ for $4 \mathrm{~h}$, then studied for their ability to migrate in response to $20 \mathrm{ng} / \mathrm{ml}$ VEGF for $4 \mathrm{~h}$. After incubation, filters were fixed and stained with Diff-Quick (Mertz-Dade). The number of cells present in five fields/well was counted at $\times 400$ magnification. Data are reported as number of cells counted/well.

\section{Caspase-3 activity}

A total of $4 \times 10^{5}$ cells were plated in $10 \%$ serum, starved $(0.1 \%$ serum $)$ for $24 \mathrm{~h}$, and then stimulated with $50 \mu \mathrm{M} \mathrm{A} \beta_{1-40 / 40-1}$ for $16 \mathrm{~h}$. Enzyme activity was detected in supernatants by measuring the proteolytic cleavage of fluorogenic substrate of caspase-3 (Z-DEVD-R110) in assay buffer provided by the kit. The fluorescence was measured by using SpectraFluor (Tecan) (excitation/emission 485/535) every 30 min within $3 \mathrm{~h}$. Data are reported as relative fluorescence/mg protein \pm s.e.m. ${ }^{39}$ For immunohistochemistry analysis, $15 \times 10^{3}$ cells were plated in $10 \%$ serum, starved overnight and then stimulated with $\mathrm{A} \beta_{1-40}(0.5$ and $5 \mu \mathrm{M})$ and $\mathrm{A} \beta_{40-1}(5 \mu \mathrm{M})$. Medium was removed and the cells were washed with PBS with $\mathrm{Ca}^{2+}$ and $\mathrm{Mg}^{2+}$ and then fixed in cold acetone for $5 \mathrm{~min}$. Cells were then incubated with primary antibody anti-cleaved caspase-3 (Cell Signaling, Beverly, MA, USA) diluted $1: 35$ in PBS with $0.5 \%$ BSA overnight at $4{ }^{\circ} \mathrm{C}$. Then the secondary antibody (goat-anti-mouse IgGTRITC diluted $1: 50$ ) was added for $1 \mathrm{~h}$ at room temperature. The cells were mounted in Mowiol (Calbiochem, VWR International srl, Italy) and then observed by fluorescence microscope (Nikon, Eclipse3000).

\section{Tunel assay}

Apoptosis was determined by using ApopTag ${ }^{\circledR}$ Plus Fluorescein In Situ Apoptosis Detection Kit (Chemicon) following kit protocol. Briefly, $25 \times 10^{3}$ CVEC cells were seeded on cover slides in a 24 multiwell plate. Cells were starved for $24 \mathrm{~h}$ and then stimulated with $\mathrm{A} \beta_{1-40}(5 \mu \mathrm{M})$, FGF-2 $(20 \mathrm{ng} / \mathrm{ml})$ or $\mathrm{A} \beta_{40-1}(5 \mu \mathrm{M})$ for $16 \mathrm{~h}$. Cells were counterstained with DAPI as indicated by the kit. Original magnification was at $\times 400$.

\section{Western blot}

A total of $3 \times 10^{5}$ cells were plated in $60 \mathrm{~mm}$ diameter dishes. After adhesion, cells were serum starved for $24 \mathrm{~h}$, then exposed to test substances following different protocols. To evaluate the effect of $A \beta$ peptides on VEGF-induced ERK $1 / 2$ phosphorylation, ECs were preincubated with $\mathrm{A} \beta_{1-40}(5 \mu \mathrm{M})$ for $16 \mathrm{~h}$ and then stimulated with $20 \mathrm{ng} / \mathrm{ml}$ VEGF for $10 \mathrm{~min}$. To assess the effect of $A \beta$ peptides on FGF-2, cells were treated with $\mathrm{A} \beta_{1-40}(0.5-50 \mu \mathrm{M})$ for $16 \mathrm{~h}$. For Akt phosphorylation cells were exposed to FGF-2 $(20 \mathrm{ng} / \mathrm{ml})$ for $15 \mathrm{~min}$ in the presence/absence of $\mathrm{A} \beta_{1-40}(5 \mu \mathrm{M})$. After incubation with test substances, Western blots were performed as described. ${ }^{16}$ Results were normalized to those obtained by using an antibody to total ERK1/2 (for phospho-ERK1/2), to actin (for FGF-2) or to total Akt (phospho-Akt).

\section{Immunoprecipitation}

CVEC $\left(5 \times 10^{5}\right)$ were seeded in $60 \mathrm{~mm}$ diameter dishes. After adherence cells were harvested $(0.1 \%$ serum $)$ overnight and then stimulated with $\mathrm{A} \beta_{1-40}(5 \mu \mathrm{M})$ in the presence/absence of FGF-2 $(20 \mathrm{ng} / \mathrm{ml})$ for $15 \mathrm{~min}$. Cells were then lysed and lysates were scraped from the dishes and precleared by centrifugation at $10000 \mathrm{~g}$ for $25 \mathrm{~min}$ at $4^{\circ} \mathrm{C}$. Anti eNOS antibody $(5 \mu \mathrm{g} / \mathrm{ml})$ was then added to the precleared lysates for $2 \mathrm{~h}$ at $4^{\circ} \mathrm{C}$, followed by an overnight incubation at $4^{\circ} \mathrm{C}$ with protein $\mathrm{G}(50 \mu \mathrm{l})$. Immunoprecipitates were washed twice in $1 \mathrm{ml}$ of sample buffer, boiled for $5 \mathrm{~min}$ and separated in SDS/polyacrilamide (8\%) gels and electroblotted onto nitrocellulose membranes. Immunoblots were incubated with anti HSP90 antibody.

\section{Determination of nitric oxide synthase (eNOS) activity}

NOS activity was measured in CVEC and MAE as previously described, ${ }^{40}$ following different protocols. (1) CVEC were pre-incubated with $\mathrm{A} \beta_{1-40}$ $(4 \mathrm{~h})$ and then VEGF-exposed (1 h). (2) CVEC and MAE were stimulated with $\mathrm{A} \beta_{1-40}(5 \mu \mathrm{M})$ for $50 \mathrm{~min}$ or FGF-2 $(20 \mathrm{ng} / \mathrm{ml})$ for $15 \mathrm{~min}$. eNOS expressed as DPM of $\left[{ }^{3} \mathrm{H}\right]$-citrulline formed/mg protein. Negative control: LNMMA (2 mM). ${ }^{20}$ All determinations were performed in duplicate. NOS activity is expressed as pmol of $\left[{ }^{3} \mathrm{H}\right]$-citrulline formed/mg protein.

\section{Microcarrier cell culture}

Gelatine-coated cytodex microcarriers were prepared and embedded in a fibrin gel as described. ${ }^{41}$ Stimuli ( $20 \mathrm{ng} / \mathrm{ml}$ VEGF, $5 \mu \mathrm{M} \mathrm{A} \beta_{1-40}$ alone or together with VEGF) were added. Stimuli were replaced after 2 days. At days 1-7 after the polymerization of the gels, the area occupied by capillary-like formations was quantified by an inverted microscope at a magnification of $\times 200$, using an ocular grid. The area is expressed as the number of grid units required to cover all the pseudocapillary surface. Results are reported as mean area unit \pm s.e.m.

\section{Heparin binding}

$10 \mu \mathrm{l}$ of heparin-acrylic beads were incubated with increasing concentrations of $\mathrm{A} \beta_{1-40}(0.5 \mathrm{nM}$ to $50 \mu \mathrm{M})$ in $40 \mu \mathrm{l}$ PBS for $1 \mathrm{~h}$ at $37^{\circ} \mathrm{C}$. Then $25 \mathrm{ng}$ of FGF-2 was added, and the beads were incubated for $2 \mathrm{~h}$ at $37^{\circ} \mathrm{C}$. After incubation, the beads were washed three times with PBS, and bound FGF-2 was removed from the beads by boiling in sample buffer and then separated by SDS-PAGE in $18 \%$ polyacrylamide gel. Western blotting was performed with anti-FGF-2 antibody and filters were visualized by enhanced chemiluminescence. Experiment was performed at least three times. 


\section{Angiogenesis in vivo: rabbit cornea assay}

Corneal assays were performed in New Zealand white rabbits (Charles River, Lecco, Italy) ${ }^{38}$ in accordance with the guidelines of the European Economic Community for animal care and welfare (EEC Law No.86/609). After corneal enrichment with $\mathrm{A} \beta_{1-40}, \mathrm{~A} \beta$ peptide-bearing pellets were substituted with VEGF165-releasing pellets. The angiogenic response in the presence of $A \beta$ peptide was compared to parallel implants with vehicle alone in the contralateral eye. Subsequent daily observation of the implants was made with a slit-lamp stereomicroscope without anaesthesia. Angiogenesis was followed for 2 weeks; an angiogenic score was recorded at each observation (independent observer) and calculated as previously described. ${ }^{38}$ Data are reported as angiogenic score during time (days).

\section{Statistical analysis}

Results are expressed as means \pm s.e.m. Statistical analysis were performed using Student's $t$-test, and analysis of variance (ANOVA). $P<0.05$ was considered significant.

\section{Reagents}

$\mathrm{A} \beta_{1-40}, \mathrm{~A} \beta_{40-1}, \mathrm{~N}^{\mathrm{G}}$-monomethil-L-arginine (LNMMA), reagents for cell cultures and heparin-acrylic beads (Sigma). [ $\left.{ }^{3} \mathrm{H}\right]$-L-arginine, VEGF165 were from Amersham Biosciences, and Peprotech (Italy), respectively. Anti-phospho-ERK1/2, anti-ERK1/2, anti-phospho-Akt, anti-Akt, anticleaved caspase-3, and anti-HSP90 antibodies (Cell Signalling). AntieNOS antibody was purchased from Promega (Italy).

\section{Acknowledgements}

We thank Professor M Presta (University of Brescia, Italy) for providing the cells used in this study (MAE, pZIPbFGF, CHO-FGFR-1). This work was supported by the Italian Ministry for University and Research (PRIN project no. 2004065317_001 and FIRB project no. RBNE01458S_007, RBNE01M9HS_002 and RBNE01A882_002) (to M.Z.) and from the University of Siena (PAR project 2004) (to M.Z.). Siena Biotech, SBA, and MPS (Monte dei Paschi) Foundation, Siena, are also acknowledged for their contribution.

\section{References}

1. Kalaria RN, Cohen DL, Premkumar DR, Nag S, LaManna JC and Lust WD (1998) Vascular endothelial growth factor in Alzheimer's disease and experimental cerebral ischemia. Brain Res. Mol. Brain Res. 62: 101-105

2. Brion J, Passareiro E, Nunez J and Flament-Durand J (1985) Mise en evidence immunologique de la protein tau au niveau des lesions de degenerescence neurofibrillaire de la maladie D'Alzheimer. Arch. Biol. 95: 229-235

3. Kosik KS, Joachim CL and Selkoe DJ (1986) Microtubule-associated protein tau, is a major antigenic component of paired helical filaments in Alzheimer's disease. Proc. Natl. Acad. Sci. USA 83: 4044-4048

4. Dickson DW (1997) The pathogenesis of senile plaques. J. Neuropathol. Exp. Neurol. 56: 321-339

5. Haass $C$, Schlossmacher M, Hung AY, Vigo-Pelfrey C, Mellon A, Ostaszewski B, Lieberburg I, Koo EH, Schenk D, Teplow D and Selkoe DJ (1992) Amyloid- $\beta$ peptide is produced by cultured cells during normal metabolism. Nature 359 : $322-325$

6. Vinters (1987) Cerebral amyloid angiopathy: a critical review. Stroke 18 $311-324$
7. Greenberg SM, Vonsattel JP, Segal AZ, Chiu RI, Clatworthy AE, Liao A, Hyman BT and Rebeck GW (1998) Association of apolipoprotein E epsilon2 and vasculopathy in cerebral amyloid angiopathy. Neurology 50: 961-965

8. Miravalle L, Tokuda T, Chiarle R, Giaccone G, Bugiani O, Tagliavini F, Frangione B and Ghiso J (2000) Substitutions at codon 22 of Alzheimer's abeta peptide induce diverse conformational changes and apoptotic effects in human cerebral endothelial cells. J. Biol. Chem. 275: 27110-27116

9. Herzig MC, Winkler DT, Burgermeister P, Pfeifer M, Kohler E, Schmidt SD, Danner S, Abramowski D, Sturchler-Pierrat C, Burki K, van Duinen SG, MaatSchieman ML, Staufenbiel M, Mathews PM and Jucker M (2004) Abeta is targeted to the vasculature in a mouse model of hereditary cerebral hemorrhage with amyloidosis. Nat. Neurosci. 7: 954-960. Epub 2004 Aug 15

10. Price JM, Sutton ET, Hellermann A and Thomas T (1997) Beta amyloid induces cerebrovascular endothelial dysfunction in rat brain. Neurological Res. 19: $534-538$

11. Thomas T, Thomas G, McLendon C, Sutton T and Mullan M (1996) $\beta$-Amyloidmediated vasoactivity and vascular endothelial damage. Nature 380: 168-171

12. Beckmann N, Schuler A, Mueggler T, Meyer EP, Wiederhold KH, Staufenbiel M and Krucker T (2003) Age-dependent cerebrovascular abnormalities and blood flow disturbances in APP23 mice modeling Alzheimer's disease. J. Neurosci. 23: 8453-8459

13. Sutton ET, Hellermann GR and Thomas T (1997) Beta-amyloid-induced endothelial necrosis and inhibition of nitric oxide production. Exp. Cell Res. 230: 368-376

14. Paris D, Townsend K, Quadros A, Humphrey J, Sun J, Brem S, WotoczekObadia M, DelleDonne A, Patel N, Obregon DF, Crescentini R, Abdullah L, Coppola D, Rojiani AM, Crawford F, Sebti SM and Mullan M (2004) Inhibition of angiogenesis by Abeta peptides. Angiogenesis 7: 75-85

15. Atwood CS, Obrenovich ME, Liu T, Chan H, Perry G, Smith R and Martins RN (2003) Amyloid-beta: a chameleon walking in two worlds: a review of the trophic and toxic properties of amyloid-beta. Brain Res. Rev. 43: 1-16

16. Cantara S, Donnini S, Morbidelli L, Giachetti A, Schulz R, Memo M and Ziche M (2004) Physiological levels of amyloid peptides stimulate the angiogenic response through FGF-2. FASEB J. 18: 1943-1945

17. Gualandris A, Rusnati M, Belleri M, Nelli EE, Bastaki M, Molinari-Tosatti MP, Bonardi F, Parolini S, Albini A, Morbidelli L, Ziche M, Corallini A, Possati L, Vacca A, Ribatti D and Presta M (1996) Basic fibroblast growth factor overexpression in endothelial cells: an autocrine mechanism for angiogenesis and angioproliferative diseases. Cell Growth Differ. 7: 147-160

18. Ribatti D, Gualandris A, Belleri M, Massardi L, Nico B, Rusnati M, Dell'Era P, Vacca A, Roncali $L$ and Presta M (1999) Alterations of blood vessel development by endothelial cells overexpressing fibroblast growth factor-2. J. Pathol. 189: 590-599

19. Guimond S, Maccarana M, Bradley B, Olwin B, Lindhal U and Rapraeger AC (1993) Activating and inhibitory heparin sequences for FGF-2 (Basic FGF). JBC. 268: 23906-23914

20. Ziche M, Morbidelli L, Choudhuri R, Zhang HT, Donnini S, Granger HJ and Bicknell R (1997) Nitric oxide synthase lies downstream from vascular endothelium growth factor-induced but not basic fibroblast growth factorinduced angiogenesis. J. Clin. Invest. 99: 2625-2634

21. Papapetropoulus A, Fulton D, Mahboudi K, Kalb RG, O'Conner DS, Li F, Altieri DC and Sessa WC (2000) Angiopoietin-1 inhibits endothelial cell apoptosis via the Akt/Survivin pathway. JBC. 275: 9102-9105

22. Ajmani RS, Metter EJ, Jaycumar R, Ingram D and Rifkind JM (2000) Hemorheological changes during aging associated with cerebral blood flow and impaired cognitive function. Neurobiol. Aging 21: 257-270

23. Gentile MT, Vecchione C, Maffei A, Aretini A, Marino G, Poulet R, Capobianco L, Selvetella $G$ and Lembo $G$ (2004) Mechanisms of soluble beta-amyloid impairment of endothelial function. J. Biol. Chem. 279: 48135-48142

24. Xu J, Chen S, Ku G, Ahmed SH, Xu J, Chen H and Hsu CY (2001) Amyloid beta peptide-induced cerebral endothelial cell death involves mitochondrial dysfunction and caspase activation. J. Cereb. Blood Flow Meta. 21: $702-710$

25. Yin KJ, Lee JM, Chen SD, Xu J and Hsu CY (2002) Amyloid-beta induces Smac release via AP-1/Bim activation in cerebral endothelial cells. J. Neurosci. 22: 9764-9770

26. Langford D, Hurford R, Hashimoto M, Digicaylioglu M and Masliah E (2005) Signalling crosstalk in FGF2-mediated protection of endothelial cells from HIV-gp120 BMC. Neuroscience 6: 8 
27. Guo Q, Sebastian L, Sopher BL, Miller MW, Glazner GW, Ware CB, Martin GM and Mattson MP (1999) Neurotrophic factors [activity-dependent neurotrophic factors (ADNF) and basic fibroblast growth factor (bFGF)] interrupt excitotoxic neurodegenerative cascades promoted by a PS1 mutation. Proc. Natl. Acad. Sci. USA 96: 4125-4130

28. Kroll J and Waltenberger J (1999) A novel function of VEGF receptor-2 (KDR) rapid release of nitric oxide in response to VEGF-A stimulation in endothelial cells. Biochem. Biophys. Res. Commun. 265: 636-639

29. Ferrara N, Gerber HP and LeCouter J (2000) The biology of VEGF and its receptors. Nat. Med. 9: 669-676

30. Suhara T, Magrane J, Rosen K, Christensen R, Kim HS, Zheng B, McPhie DL, Walsh K and Querfurth $\mathrm{H}$ (2003) Abeta42 generation is toxic to endothelial cells and inhibits eNOS function through an Akt/GSK-3beta signaling-dependent mechanism. Neurobiol. Aging 24: 437-451

31. Ziche M, Parenti A, Ledda F, Dell'Era P, Granger H, Maggi C and Presta M (1997) Nitric oxide promotes proliferation and plasminogen activator production by coronary venular endothelium through endogenous bFGF. Circ. Res. 80 : 845-852

32. Martinez-Ruiz A, Villanueva L, Gonzalez de Orduna C, Lopez-Ferrer D, Higueras MA, Tarin C, Rodriguez-Crespo I, Vazquez J and Lamas S (2005) S-nitrosylation of $\mathrm{Hsp} 90$ promotes the inhibition of its ATPase and endothelia nitric oxide synthase regulatory activities. PNAS 102: 8525-8530

33. de la Torre JC (2002) Alzheimer's disease: how does it start? J. Alzheimers Dis. 4: 497-512. Review

34. Williams D, Davenport $K$ and Tan $Y$ (2003) Angiogenesis with recombinant fibroblast growth factor-2 for claudication. Lancet 361: 256
35. Yoshimura S, Teramoto T, Whalen MJ, Irizarry MC, Takagi Y, Qiu J, Harada J, Waeber C, Breakefield XO and Moskowitz MA (2003) FGF-2 regulates neurogenesis and degeneration in the dentate gyrus after traumatic brain injury in mice. J. Clin. Invest. 112: 1202-1210

36. Quarto N, Talarico D, Sommer A, Florkiewicz R, Basilico C and Rifkin DB (1989) Transformation by basic fibroblast growth factor requires high levels of expression: comparison with transformation by hst/K-fgf. Oncogene Res. 5 : $101-110$

37. Casu B, Guerrini M, Naggi A, Perez M, Torri G, Ribatti D, Carminati P, Giannini G, Penco S, Pisano C, Belleri M, Rusnati M and Presta M (2002) Short heparin sequences spaced by glycol-split uronate residues are antagonists of fibroblast growth factor 2 and angiogenesis inhibitors. Biochemistry 41 : 10519-10528

38. Morbidelli L, Donnini S, Chillemi F, Giachetti A and Ziche M (2003) Angiosuppressive and angiostimolatory effects exerted by synthetic partial sequences of endostatin. Clin. Cancer Res. 9: 5358-5369

39. Cantara S, Donnini S, Giachetti A, Thorpe PE and Ziche M (2004) Exogenous $\mathrm{BH} 4 / \mathrm{Bcl}-2$ peptide reverts coronary endothelial cell apoptosis induced by oxidative stress. J. Vasc. Res. 41: 202-207

40. Parenti A, Morbidelli L, Cui XL, Douglas JG, Hood JD, Granger HJ, Ledda F and Ziche M (1998) Nitric oxide is an upstream signal of vascular endothelial growth factor-induced extracellular signal-regulated kinase $1 / 2$ activation in postcapillary endothelium. J. Biol. Chem. 273: 4220-4226

41. Nehls V and Drenckhahn D (1995) A novel, microcarrier-based in vitro assay for rapid and reliable quantification of three-dimensional cell migration and angiogenesis. Microvascular Research 50: 311-322 